\title{
Turist Rehberliği Öğrencilerinin Mesleki Eğitime Yönelik Görüşleri: Balıkesir Üniversitesi Örneği*
}

\author{
Seda Şahin ${ }^{1}$ (D) Mervenur Erdem ${ }^{2 * *}$ (D) \\ ${ }^{1}$ Balıkesir Üniversitesi, Turizm Fakültesi, ssen@balikesir.edu.tr, ORCID: 0000-0001-5977-1561 \\ 2 Balıkesir Üniversitesi, Sosyal Bilimler Enstitüsü, mrvnrerdem@gmail.com, ORCID: 0000-0001-8965-7874
}

Öz

Turist rehberleri, kişilerin ziyaret ettikleri yer ile ilgili, tarihi, arkeolojik, mitolojik, kültürel bilgiler veren, en az bir yabancı dil bilen yol göstericilerdir. Turist rehberlerinin pek çok alanda bilgi sahibi olması ve gidilen yöreyi en doğru şekilde tanıtmaları gerekmektedir. Turist rehberleri ayrıca ülkesel ve bölgesel açıdan katkı sağlayan bir yapıya sahiptir. Turist rehberlerinin ziyaretçilere doğru ve faydalı bilgiler verebilmesi için ise nitelikli bir eğitim sürecinden geçmeleri gerekmektedir. Bu açıdan turist rehberliği eğitimi alan öğrencilerin mesleki eğitime yönelik görüşlerinin belirlenmesi turist rehberliği eğitimine katkı sunarak nitelikli rehberlerin yetişmesini sağlayacaktır. Yapılan araştırmada yarı yapılandırılmış görüşme formu aracılığıyla öğrencilerin turist rehberliği eğitimine yönelik görüşlerinin ve beklentilerinin belirlenmesi amaçlanmıştır. Bu amaç doğrultusunda Balıkesir Üniversitesi Turizm Fakültesi Turizm Rehberliği Bölümü’nde eğitim görmekte olan birinci, ikinci, üçüncü, dördüncü sınıf ve birinci, ikinci öğretim öğrencilerinden en az 10 öğrenci ile görüşme yapılması hedeflenmiştir. Yarı yapılandırılmış görüşme formunu cevaplamaya istekli olan toplamda 84 öğrenciyle araştırma gerçekleştirilmiştir. Elde edilen veriler kodlama ve içerik analizi yöntemleriyle çözümlenmiştir. Analizler sonucunda 17 kategori ve kategorilerde yer alan 197 ifade belirlenmiştir. Analizler sonucu elde edilen bilgilere göre turist rehberliği öğrencilerinin mesleki eğitime yönelik olumlu görüşlere sahip olduğu, fakülte ve TUREB'e yönelik uygulamalı eğitim, ders içeriklerinin çeşitlendirilmesi ve nitelikli bir yabancı dil eğitimi beklentisinde oldukları belirlenmiştir.

Anahtar Kelimeler: Turist Rehberliği, Mesleki Eğitim, Beklenti

Tourist guiding students' view on vocational education: The case of Balıkesir University

Abstract

Tourist guides are leaders who provide historical, archaeological, mythological and cultural information about the place tourists are visiting, and who speak at least one foreign language. Tourist guides need to have knowledge in many areas and introduce the destination in the most accurate way. Tourist guides also contribute to the country and the region. In order to provide accurate and useful information to visitors, they must undergo a qualified education process. In this respect, determining the views of the students who receive tourist guiding education towards vocational education will contribute to tourist guiding education and will ensure the training of qualified guides. The study aimed to determine the students' views and expectations on tourist guiding education through a semistructured interview form. For this purpose, it is aimed to interview with at least 10 students from the first, second, third, fourth year and daytime and evening education students studying at the Tourism Guidance Department of Balıkesir University Faculty of Tourism. The research was conducted with 84 students in total who were willing to answer the semi-structured interview form. The data obtained have been analyzed using coding and content analysis methods. As a result of the analyses, 17 categories and 197 expressions in the categories have been identified. According to the information obtained from the analysis, it has been determined that the tourist guiding students had positive views towards vocational education and that they expected practical training for faculty and TUREB, diversification of course content and a qualified foreign language education.

Keywords: Tourist Guiding, Vocational Education, Expectation

\section{Araştırma Makalesi}

Cilt 5, Sayı 1, 2021

ss. $92-116$

Gönderim : 11.01.2021

1. Düzeltme: 03.03.2021

Kabul Tarihi: 09.03.2021

Research Article

Vol 5, No 1, 2021

pp. 92-116

Received : 11.01.2021

Revision1: 03.03.2021

Accepted: 09.03.2021

\section{Önerilen Atıf/Suggested Citation}

Şahin, S. ve Erdem, M. (2021). Turist Rehberliği Öğrencilerinin Mesleki Eğitime Yönelik Görüşleri: Balıkesir Üniversitesi Örneği.

Güncel Turizm Araştırmaları Dergisi, 5(1), 92-116.

*Bu çalışma 5- 6 Kasım 2020 tarihinde gerçekleştirilen 3. Ulusal Turist Rehberliği Kongresinde bildiri olarak sunulmuştur.

**Sorumlu yazar e-posta: mrvnrerdem@gmail.com 


\section{GİRIŞ}

Turizm, yaşanan kültürel, ekonomik ve teknolojik gelişmeler sayesinde kişilerin merak, keşfetme ve deneyimleme duyguları ile birleşerek uluslararası boyutta bir olay haline gelmiştir. Turizm hareketinin yaygınlaşması hizmet kalitesi arayışlarını da beraberinde getirmektedir (Kurgun, 2018). Turistler, gezip gördükleri yerler hakkındaki meraklarını giderecek yol göstericilere ihtiyaç duymaktadır. Turistlere gezip gördükleri tarihi, kültürel, doğal güzellikler ile ilgili bilgileri veren kişiler ise turist rehberleridir. Turist rehberi bir ülkenin veya bölgenin en doğru ve objektif şekilde tanınmasını sağlamaktadır. Turist rehberi ziyaretçilere bilgilendirme yaparken arkeoloji, mitoloji, sanat tarihi, dinler tarihi, antik medeniyetler gibi pek çok konuya hâkim olmalıdır. Turist rehberinin anlatımları kişilerin ülkeyi tekrar ziyaret etme, tavsiye etme niyetlerine etki etmekte ülke imajına katkı sağlamaktadır. Bu açıdan turist rehberlerinin turizme katkısı yadsınamayacak boyutlardadır. Bu nedenle turist rehberlerinin nitelikli bir eğitim sürecinden geçmeleri önemlidir.

Türkiye' de turist rehberliği eğitimi 1995 yllına kadar Kültür ve Turizm Bakanlığ tarafından açılan kurs programlarıyla sınırlı kalmıştır (Değirmencioğlu, 1998). Üniversiteler bünyesinde iki yıllık ön lisans, dört yıllık lisans ve lisansüstü düzeyde eğitim verilmeye başlanması ise 1995 sonrası dönemde gerçekleşmiştir (Eker, 2015). $\mathrm{Bu}$ dönemden sonra turist rehberliği eğitimi almak için birden fazla seçenek bulunması ve eğitimleri farklı derecelerde alan kişilerin aynı imkânlara sahip olması, bilgi aktarımı ve fırsat eşitliği konusunda sorunlar yaşanmasına neden olmaktadır (Şahin ve Şahin, 2007). Bu nedenle turist rehberliği eğitiminin gözden geçirilmesi, varsa sorunların tespit edilmesi ve çözümlenmesi yolunda adımlar atılması önem arz etmektedir. Eğitim sürecinde yaşanan avantaj ya da dezavantajları en iyi şekilde gözleyen taraf olarak öğrencilerin bu konudaki düşüncelerinin belirlenmesi son derece önemlidir. Bu doğrultuda çalışmada, turist rehberliği öğrencilerinin mesleki eğitim ile ilgili görüşlerinin ve nitelikli bir turist rehberliği eğitimine yönelik önerilerinin neler olduğunun belirlenmesi amaçlanmıştır.

\section{LITERATÜR TARAMASI}

6326 Sayılı Turist Rehberliği Meslek Kanuna göre üniversitelerin turist rehberliği bölümlerinin önlisans, lisans veya yüksek lisans programlarından mezun olmak veya üniversitelerin turist rehberliği bölümü dışındaki diğer bölümlerinden en az lisans düzeyinde mezun olduktan sonra, birliklerin ve Türkiye Seyahat Acentaları Birliğinin ortak önerileri ve Bakanlığın onayıyla turizm sektörünün ihtiyaçları da dikkate alınarak belirlenen dillerde, gerektiği hâllerde belirlenen bölgelerde, yönetmelikle kurs ve sınavlara ilişkin belirlenen usul ve esaslar çerçevesinde Bakanlığın gözetimi ve denetimi altında birlikler tarafından düzenlenen ülkesel veya bölgesel turist rehberliği sertifika programını başarıyla tamamlamak şartıyla turist rehberi olunabilmektedir (Resmi Gazete, 2012). Türkiye'de turist rehberliği eğitiminin farklı düzey ve şekillerde veriliyor olması eğitimin niteliğinin de farklılaşmasına neden olmaktadır. 
Türkiye'de farklı nitelikte ve farklı sürede verilen rehberlik eğitiminin iki önemli olumsuz sonucu vardır. Birincisi rehberlik eğitiminde, eğitimin süresi ve niteliği açısından bir standartlaşma yoktur. Bu durum belirli standartlarda turist rehberi yetiştirilmesine engel olmaktadır. İkinci olumsuz sonuç ise farklı seviyelerde eğitim almış kişilerin aynı hakka sahip olması durumunun fırsat eşitliğine engel teşkil etmesidir (Kuşluvan ve Çeşmeci, 2002: 237). Turist rehberliği eğitiminde standardizasyonun sağlanması, nitelikli turist rehberi yetiştirilmesine katkı sağlayacağ1 gibi sektöre yaşanan fırsat eşitsizliğinin giderilmesine de katkı sağlayacaktır.

Tablo 1: Turist Rehberliği Eğitimi Alan Öğrencilerin Mesleki Eğitime Yönelik Görüşlerini Belirlemeyi Amaçlayan Çalışmalar

\begin{tabular}{|c|c|c|}
\hline Araştırmacı(lar) & Araştırmanın Yapıldığı Yil & Amaç, İçerik ve Anahtar Kelimeler \\
\hline \multirow[t]{5}{*}{ Hacıoğlu } & 2008 & $\begin{array}{l}\text { Amaç: Turist rehberliği eğitimine yeni bir } \\
\text { yaklaşım getirilmesi }\end{array}$ \\
\hline & & Turist rehberlerinin stratejik önemi \\
\hline & & $\begin{array}{l}\text { Turist rehberliği eğitiminin tek bir düzeyde } \\
\text { verilmesi böylelikle hizmet kalitesinin } \\
\text { yükseltilmesine katkı sağlanması }\end{array}$ \\
\hline & & $\begin{array}{l}\text { Turist rehberliği alanında lisansüstü eğitimin } \\
\text { gerekliliği }\end{array}$ \\
\hline & & $\begin{array}{l}\text { Turist rehberliği eğitiminde nadir dillerin ön } \\
\text { plana çıkarılması }\end{array}$ \\
\hline \multirow[t]{4}{*}{ Yıldız ve Demirel } & 2008 & $\begin{array}{l}\text { Amaç: Kültür ve Turizm } \text { Bakanlığı kurs } \\
\text { programının incelenmesi }\end{array}$ \\
\hline & & Türkiye'deki turist rehberliği eğitimi \\
\hline & & $\begin{array}{l}\text { Turist rehberliği eğitiminde bir standartın } \\
\text { belirlenmesi gerekliliği }\end{array}$ \\
\hline & & $\begin{array}{l}\text { Farklı düzeylerde eğitim alan öğrencilerin } \\
\text { meslek hayatında aynı haklara sahip olmasının } \\
\text { oraya çıardığı fırsat eşitsizliği }\end{array}$ \\
\hline \multirow[t]{3}{*}{ Yilmaz } & 2011 & $\begin{array}{l}\text { Amaç: Turist rehberliği öğrencilerinin mesleğe } \\
\text { bakış açlarının belirlenmesi }\end{array}$ \\
\hline & & Mesleğe yönelik olumlu tutum geliştirme \\
\hline & & $\begin{array}{l}\text { İşin doğası ve sosyal statü bölüme yönelik } \\
\text { tutumları etkilemekte }\end{array}$ \\
\hline \multirow[t]{4}{*}{$\begin{array}{l}\text { Karaman, } \\
\text { Köroğlu }\end{array}$} & 2012 & $\begin{array}{l}\text { Amaç: Turist rehberliği öğrencilerinin rehberlik } \\
\text { eğitimine yönelik görüşlerinin belirlenmesi }\end{array}$ \\
\hline & & $\begin{array}{l}\text { Öğrencilerin turist rehberliği eğitimini yetersiz } \\
\text { görmeleri }\end{array}$ \\
\hline & & $\begin{array}{l}\text { Turist rehberliği eğitiminin lisans düzeyinde } \\
\text { verilmesi gerektiği }\end{array}$ \\
\hline & & Tatbikat gezisi ile ilgili tutum geliştirme \\
\hline Tür & 2012 & $\begin{array}{l}\text { Amaç: Turist rehberliği eğitiminde karşılaşılan } \\
\text { sorunlara çözüm önerileri getirilmesi }\end{array}$ \\
\hline
\end{tabular}




\begin{tabular}{|c|c|c|}
\hline & & Mesleğin tanınırlığının artırılması gerektiği \\
\hline & & Eğitimcilerin yeterlilik düzeyleri \\
\hline & & $\begin{array}{l}\text { Turist rehberliği eğitiminin lisans düzeyinde } \\
\text { verilmesi }\end{array}$ \\
\hline & & Mesleki derslerin içeriğinin düzenlenmesi \\
\hline & & $\begin{array}{l}\text { Meslek odaları- bakanlık- üniversite iş birliğinin } \\
\text { sağlanması }\end{array}$ \\
\hline Erdem ve Etiz & 2012 & $\begin{array}{l}\text { Amaç: Tatbikat gezisi ile ilgili algıların } \\
\text { belirlenmesi }\end{array}$ \\
\hline & & Turist rehberliği eğitimine yönelik memnuniyet \\
\hline & & Tatbikat gezisinin pratik açıdan katkı sağlaması \\
\hline $\begin{array}{l}\text { Aymankuy, Aymankuy, } \\
\text { Tetik ve Girgin }\end{array}$ & 2013 & $\begin{array}{l}\text { Amaç: Lisans düzeyinde turizm eğitimine } \\
\text { öğrencilerin ve akademisyenlerin bakışlarının } \\
\text { belirlenmesi }\end{array}$ \\
\hline & & Staj süresinin uzun olması gerektiği \\
\hline & & Sektör içinde turist rehberliğinin yeri \\
\hline & & $\begin{array}{l}\text { Stajın hem akademisyenler hem de öğrenciler } \\
\text { açısından gerekli görülmesi }\end{array}$ \\
\hline Esen ve Gülmez & 2018 (a) & $\begin{array}{l}\text { Amaç: Turist rehberliği öğrencilerinin uygulama } \\
\text { gezisi ile ilgili düşüncelerin belirlenmesi }\end{array}$ \\
\hline & & $\begin{array}{l}\text { Uygulama gezisindeki eğitimin mesleki açıdan } \\
\text { olumlu katkıları }\end{array}$ \\
\hline Aydın ve Korkmaz & 2018 & $\begin{array}{l}\text { Amaç: Turist rehberliği öğrencilerinin staja } \\
\text { uygulamalarına } \\
\text { belirlenmesi }\end{array}$ \\
\hline & & Teorik eğitimin pratik eğitimi pekiştirmesi \\
\hline & & Stajın eğitimi tamamlaması \\
\hline Temizkan ve Cankül & 2018 & $\begin{array}{l}\text { Amaç: Turist rehberliği öğrencilerinin mesleki } \\
\text { eğitime ve mesleğe kabul şartlarına karş1 } \\
\text { tutumlarının belirlenmesi }\end{array}$ \\
\hline & & $\begin{array}{l}\text { Turist rehberliği eğitiminin lisans düzeyinde } \\
\text { verilmesi gerektiği }\end{array}$ \\
\hline & & Uzmanlık eğitimlerinin zorunlu hale getirilmesi \\
\hline & & $\begin{array}{l}\text { Yabancı dil yeterliliği konusunda bir standart } \\
\text { belirlenmesi }\end{array}$ \\
\hline Kurnaz Akyurt ve Kurnaz & 2018 & $\begin{array}{l}\text { Amaç: Turist rehberliği önlisans öğrencilerinin geleceğe } \\
\text { ait görüşlerinin belirlenmesi }\end{array}$ \\
\hline & & Öğrencilerin bölümü isteyerek seçtikleri \\
\hline & & Geleceğe yönelik düşük kaygı düzeyi \\
\hline & & Akademik kariyer hedefi \\
\hline Esen ve Gülmez & 2018 (b) & $\begin{array}{l}\text { Amaç: uygulama gezisinin öğrenciler açısından } \\
\text { öneminin turist rehberleri ve akademisyenler } \\
\text { tarafından değerlendirilmesi }\end{array}$ \\
\hline & & $\begin{array}{l}\text { Uygulama gezisinin bilgi sağlaması, mesleğe dair fikir } \\
\text { vermesi ve mesleğin nasıl icra edilmesi gerektiği ile } \\
\text { ilgili pratik bilgiler vermesi }\end{array}$ \\
\hline
\end{tabular}


Turist rehberliği eğitimi ile ilgili literatür incelendiğinde Türkiye' de turist rehberliği eğitimine yeni bir yaklaşım getirmek isteyen (Hacıoğlu, 2008), Kültür ve Turizm Bakanlığının kurs programını inceleyen (Yıldız ve Demirel, 2008), lisans düzeyinde turist rehberliği eğitimi alan öğrencilerin mesleğe bakış açılarını inceleyen (Yılmaz, 2011) çalışmalara rastlanmıştır. Bunun dışında turist rehberliği eğitimi ile ilgili çalışmaların genellikle turist rehberliği öğrencilerinin staj sorunlarını (Aymankuy vd., 2012; Aydın ve Korkmaz, 2018) veya tatbikat gezilerini (Erdem ve Etiz, 2012; Esen ve Gülmez, 2018a; Esen ve Gülmez, 2018b) ele alan çalışmalar olduğu belirlenmiştir. Turist rehberliği eğitimini öğrencilerin görüşleri üzerinden değerlendiren az sayıda çalışmaya rastlanmıştır (Karaman vd., 2012, Tür, 2012). Türkiye'de turist rehberliği eğitimine yönelik öğrencilerin görüşlerini içerik analizi ile değerlendiren yerli ve yabancı bir çalışmaya rastlanmamıştır.

Hacıoğlu tarafından 2008 yılında gerçekleştirilen araştırmada, Türkiye' de profesyonel turist rehberliği eğitimine yeni bir yaklaşım geliştirmek amaçlanmıştır. Turist rehberlerinin ülke ve bölgesel açıdan stratejik öneme sahip olduğu vurgulanmıştır. Turist rehberliği eğitimi üç farklı düzeyde verildiğinden dolayı haksız rekabete neden olduğunu, farklı düzeylerde verilen eğitimin sahadaki anlatımlara yansıdığını, bu durumun da sektördeki hizmet kalitesini etkilediği belirtilmiştir. Lisans düzeyinde herhangi bir bölümde eğitim görmüş öğrencilerin rehberlik bölümünde yüksek lisans yapmasının gerekliliği belirtilmiştir. Bununla birlikte rehberlik eğitiminde verilen dil eğitiminin nadir diller ile zenginleştirilmesi gerektiği vurgulanmıştır.

Yıldız ve Demirel tarafından 2008 yılında gerçekleştirilen araştırmada, Türkiye'de Profesyonel turist rehberliği eğitimi bağlamında Kültür ve Turizm Bakanlığ1 kurs programlarının incelenmesi amaçlanmıştır. Araştırmada, rehberliğin tarihçesi, rehberlerin özellikleri ve yükümlülüklerine, Türkiye'deki rehberlik eğitimine yer verilmiştir. Turizm eğitimi veren diğer ülkelerde de Türkiye' deki eğitim sorunlarının benzerleri yaşandığı görülmüştür. Araştırma sonucunda rehberlik eğitiminin iki önemli sorunu olduğuna ulaşılmıştır. Birinci sorun rehberlik eğitiminde belli bir standart olmamasıdır. İkinci sorun ise farklı şekillerde rehber olan kişilerin aynı haklara sahip olmasidir.

Yılmaz tarafından 2011 yılında gerçekleştirilen araştırma, lisans düzeyinde turist rehberliği eğitimi alan öğrencilerin mesleğe bakış açılarının belirlenmesi amaçlanmıştır. Araştırma sonuçlarına göre öğrenciler, bölümü isteyerek seçmiştir ve bölümde okumaktan mutludurlar. Mesleğe yönelik genel anlamda olumlu tavır içerisinde oldukları ancak sektörel açıdan bazı olumsuz düşüncelere sahip oldukları belirlenmiştir. Turist rehberliği bölümüne yönelik tutumlarını etkileyen unsurların işin doğası ve sosyal statü olduğu tespit edilmiştir.

Karaman, Köroğlu ve Köroğlu tarafından 2012 yılında turist rehberliği öğrencilerinin rehberlik eğitimine yönelik görüşlerinin belirlenmesi amaçlı yapılan araştırma, Balıkesir Üniversitesi Turizm İşletmeciliği ve Otelcilik Yüksekokulu Turizm Rehberliği Bölümü'nde okuyan 134 öğrenci üzerinde gerçekleştirilmiştir. Veri toplama aracı olarak anket yöntemi kullanılmıştır. Araştırma sonucunda ise öğrencilerin 
rehberlik eğitimini yetersiz buldukları, rehberlik eğitiminin lisans düzeyinde verilmesi gerektiği, tatbikat gezisi ile ilgili tutum geliştirdikleri sonucuna ulaşılmıştır.

Tür'ün 2012 yılında gerçekleştirdiği araştırma turist rehberliği eğitiminde karşılaşılan sorunlara çözüm önerileri getirmeyi amaçlamaktadır. Araştırmada rehberlik öğrencilerinin sorunları; bölümün ilk açıldı̆̆ 1992 yılında kayıt yaptıran öğrencilerin bölümü ve mesleği tanımamaları, bölümden mezun olan rehberler ve sektörde uzun zamandır çalışan rehberlerin çatışmaları şeklinde belirlenmiştir. Çalışmada ayrıca, turizm meslek lisesinden bölüme doğrudan geçiş yapan öğrenciler bir sorun olarak belirlenirken, dersleri verecek eğitimcilerin mesleki yeterliliklerinin bölüm için yetersiz görülmesi belirlenen sorunlar arasındadır. Rehberlik öğrencilerinin kokart alabilmesi için zorunlu olarak gerçekleştirmeleri gereken uygulama gezisi de bir başka sorun olarak belirlenmiştir. Çözüm önerisi olarak ise rehberlik eğitiminin sadece lisans düzeyinde verilmesi gerektiği, ders içeriklerinin rehberlik mesleğinin gereklerine uygun şekilde yenilenmesinin gerektiği, meslek liselerinin doğrudan geçiş hakkının kaldırılması gerektiği, meslek odalarının, bakanlığın ve üniversitelerdeki ilgili bölümlerin ortak bir kararla hareket etmesi gerektiğine vurgu yapılmıştır.

Erdem ve Etiz'in 2012 yılında gerçekleştirdikleri araştırmada, rehberlik tatbikat gezisi ile ilgili algılarının belirlenmesi amaçlanmıştır. Araştırma, Balıkesir Üniversitesi Turizm İşletmeciliği ve Otelcilik Yüksekokulu'nda anket yöntemi kullanılarak gerçekleştirilmiştir. Araştırmada, öğrencilerin rehberlik bölümünde eğitim almaktan memnun oldukları, bölümü isteyerek seçtikleri, tatbikat gezisinin pratik açıdan katkı sağladığını düşündükleri, gezinin içeriğinin ise en az etkili faktör olduğu sonuçlarına ulaşılmıştır.

Aymankuy, Aymankuy, Tetik ve Girgin, 2013 yılında yaptıkları lisans düzeyindeki turizm eğitimindeki staj uygulamasına öğrenci ve akademisyenlerin bakışlarının öğrenilmesi amacıyla gerçekleştirilen araştırma, Balıkesir Üniversitesi Turizm İşletmeciliği ve Otelcilik Yüksekokulu'nda öğrenci ve akademisyenlere uygulanmıştır. Araştırmaya katılan 1404 öğrenciden 183'ü turist rehberliği bölümü öğrencileridir. Araştırmanın sonucunda ise öğrencilerin staj uygulamasının süresinin daha uzun olması gerektiği, sektörün kendilerine aynı ölçüde değer vermediği, sektörde çalıştıklarında sektörde çalışma isteklerinin arttığı sonuçlarına ulaşılmıştır. Bunun yanı sıra hem akademisyenlerin hem öğrencilerin stajın önemli ve gerekli bir uygulama olduğunu düşündükleri sonucuna ulaşılmıştır.

Esen ve Gülmez'in 2018 (a) yılında gerçekleştirdiği araştırma, yurtiçi uygulama gezilerinde öğrencilerin tur kalitesi, memnuniyeti ve eğitimi ile ilgili düşüncelerini öğrenmeyi amaçlamaktadır. Veriler anket tekniği ile toplanmıştır. Araştırma sonuçlarına göre öğrenciler uygulama gezisinde verilen eğitim ile ilgili görüşleri olumludur. Öğrenciler, uygulama gezisinin mesleğin icrası için olumlu katkılar sağladı̆̆ görüşüne sahiptir.

Aydın ve Korkmaz'ın 2018 yılında gerçekleştirdiği araştırma, turist rehberliği eğitimi alan öğrencilerin staj uygulamalarına yönelik tutumlarının belirlenmesi amacıyla gerçekleştirilmiştir. Araştırma sonuçlarına göre, öğrenciler staj sürecinde sorun 
yaşamaktadırlar. Öğrenciler, okulda öğrendikleri bilgileri stajda kullandıklarını belirtmişlerdir. Bunun yanı sıra araştırma sonuçları stajın eğitim ile bir bütün olduğunu ortaya koymuştur.

Temizkan ve Cankül tarafından 2018 yılında gerçekleştirilen araştırma, turist rehberi adaylarının eğitime ve mesleğe kabul şartlarına karşı tutumunu belirlemeyi amaçlamıştır. Araştırma sonuçlarına göre öğrenciler, mesleğe kabul şartlarının uygun olduğunu belirtmişlerdir. Rehberlik eğitiminin kesinlikle lisans düzeyinde olması, uzmanlık eğitimlerinin zorunlu hale getirilmesi, yabancı dil yeterliliğine standart bir yöntem getirilmesi gerektiğini düşünmektedirler.

Kurnaz Akyurt ve Kurnaz tarafından 2018 yılında gerçekleştirilen araştırmada, ön lisans düzeyinde turist rehberliği eğitimi alan öğrencilerin geleceğe ait görüşlerinin belirlenmesi amaçlanmıştır. Araştırmanın sonucunda, turist rehberliği öğrencilerinin sevdiği bölümü okudukları, gelecek kaygılarının düşük olduğu ve akademik kariyere odaklı olduğu ortaya konmuştur.

Esen ve Gülmez tarafından 2018 (b) yılında gerçekleştirilen araştırma, turist rehberliği yurt içi uygulama gezilerinin öğrenciler açısından öneminin turist rehberleri ve akademisyenler açısından değerlendirilmesi amaçlanmıştır. Araştırmada veri toplama yöntemi olarak yarı yapılandırılmış görüşme formu uygulanmıştır. Araştırma sonuçlarına göre, uygulama gezilerinin öğrenciler açısından bilgi sağladığı için önemli ve gerekli olduğu ortaya konmuştur. Uygulama gezisinin ayrıca öğrencilerin mesleğe dair fikir sahibi olmalarını sağladığı, mesleği icra ederken nelere dikkat etmeleri gerektiğini kavramalarını sağlamaktadır.

\section{YÖNTEM}

$\mathrm{Bu}$ araştırmanın amacı turist rehberliği öğrencilerinin mesleki eğitime yönelik görüşlerinin belirlenmesidir. Bu doğrultuda ilgili alanyazın incelenmiş, öğrencilerin turist rehberliği eğitimine yönelik görüşlerini belirlemek amacıyla yarı yapılandırılmış görüşme formu hazırlanmıştır. Yarı yapılandırılmış soru formları hazırlanırken ilgili alanyazın tarandıktan sonra turist rehberliği öğrencilerinin eğitim sürecinde ve eğitim sonrası meslek hayatlarında iletişim halinde oldukları kurum ve kuruluşlar dikkate alınmıştır. Öğrencilerin bu kurum ve kuruluşlara dair beklentileri ile eğitim aldıkları süreçteki beklentilerinin, görüşlerinin ve önerilerinin neler olduğunu belirlemek amaçlanmıştır.

Yarı yapılandırılmış görüşme formunun hazırlanma aşamasında 13 uzman görüşüne başvurulmuştur. Yarı yapılandırılmış görüşme formunda yer alan sorularda görüş ve önerilerin ayrı sorular şeklinde düzenlenmesi gerektiği, yazım ve imla hatalarının gözden geçirilmesi gerektiği yönündeki görüşler doğrultusunda gerekli ilave ve düzenlemeler yapılarak görüşme formu son haline getirilmiştir. Öğrencilerle yüz yüze görüşme yapılarak mesleki eğitime yönelik görüşleri ile ilgili sorular yöneltilmiştir. Çalışmanın ana kütlesi Balıkesir Üniversitesi Turizm Fakültesi Turizm Rehberliği bölümüne 2019- 2020 eğitim öğretim yılında kayıtlı olan öğrencilerden oluşmaktadır. $\mathrm{Bu}$ araştırmanın kapsamı ulaşılabilen alanyazın ve görüşme formunu cevaplandıran 
öğrencilerle sınırlıdır. Araştırmanın evrenini Balıkesir Üniversitesi Turizm Fakültesi Turizm Rehberliği bölümünde birinci, ikinci, üçüncü ve dördüncü sinıflarda öğrenim görmekte olan birinci ve ikinci öğretim olan 573 öğrenci oluşturmaktadır. Örnekleme yöntemi olarak kota örnekleme tercih edilmiştir. Kota örnekleme yöntemi evrendeki belli değişkenlerin örnek kütlede de temsil edilebilmesi amacıyla uygulanmaktadır (Coşkun, Altunışık ve Yıldırım, 2017). Veriler 84 öğrenci ile görüşülerek toplanmıştır. Araştırmanın veri toplama sürecinde her sınıf ve her öğretim türünden en az 10 öğrenci ile görüşme yapılması hedeflenmiştir. Görüşme yapmayı kabul eden ve istekli olan öğrencilerle görüşme gerçekleştirilmiştir. Toplam 84 öğrenciden alınan görüşler araştırma kapsamına dâhil edilmiştir.

Araştırmaya katılan öğrencilerin görüşleri içerik analizi yöntemleriyle çözümlenmiştir. İçerik analizi; özellikle teknik avantajlar söz konusu olduğunda, çok miktardaki materyal ya da veri araştırmacının yorumlama yeteneğini aştığında kullanılan bir yöntemdir (Altunışık vd., 2015: 3246). Ayrıca yazılı metinlerin içeriğine bakarak en çok ya da en az hangi kavramlara, düşüncelere vurgu yapıldığ incelenerek, bir sonuca ulaşabilmek için (Kozak, 2015: 138) içerik analizi ideal bir yöntemdir. Araştırma sonucu elde edilen nitel araştırma verileri Karataş'ın (2015) belirttiği gibi sırasıyla (1) verilerin kodlanması, (2) kategorileştirme, (3) verilerin kategorilere ve kodlara göre düzenlenerek tanımlanması, (4) son olarak bulguların yorumlanması olmak üzere dört aşamada gerçekleştirilmiştir. Verilerin yorumlanmasında Yüksel ve Yüksel'in (2004) belirttiği gibi verilerin frekansı dikkate alınarak analitik yapı kullanılmıştır. Kodlamalar sonucunda elde edilen veriler kategorilere ayrılmış, Excel çalışma sayfası yardımıyla bir araya getirilip tekrarlanma sıklıkları ve yüzde dağılımları tespit edilmiştir. Araştırmanın güvenilirliğinin sağlanması amacıyla elde edilen verilerin kodlamalarının kategorileştirilmesi işlemi sırasında ve sonrasında hem araştırmacılar tarafından tartışılmış hem de başka akademisyenler ile uzman görüşlerine başvurulmuştur. Bu değerlendirmeler sonucunda kodlamaların kategorileştirilmesi konusunda uyum ve fikir birliği sağlanmış, araştırmanın güvenirliliğinin sağlandığ1 varsayılmıştır.

\section{BULGULAR}

Turist rehberliği öğrencilerinin mesleki eğitime yönelik görüşlerinin belirlenmesini amaçlayan araştırmaya 84 öğrenci katılmıştır. Araştırmaya katılan öğrencilerin demografik özelliklerine ilişkin bilgilerin frekans ve yüzde dağılımları Tablo 2' de yer almaktadir.

Araştırmaya katılan öğrencilerin \%51,19'u (n=43) kadın, \%48,81'i (n=41) erkektir. Araştırmaya katılan öğrencilerin \%26,20'si (n=22) 1. Sınıf, \%26,20'si (n=22) 2. Sınıf, $\% 23,80$ i $(n=20)$ 3. Sınıf, \%23,80'i (n=20) 4. Sinıftır. Araştırmaya katılım gösteren öğrencilerin \%50'si (n=42) 1. Öğretim, \%50'si (n=42) 2. Öğretimdir. Araştırmaya katılan öğrencilere bölümü isteyerek seçip seçmedikleri sorulmuştur. 
Tablo 2: Araştırmaya Katılan Öğrencilerin Demografik Özellikleri

\begin{tabular}{|c|c|c|}
\hline Cinsiyet & $\mathrm{n}$ & $\%$ \\
\hline Kadın & 43 & 51,19 \\
\hline Erkek & 41 & 48,81 \\
\hline Toplam & 84 & 100,00 \\
\hline Sinif & $\mathrm{n}$ & $\%$ \\
\hline 1 & 22 & 26,20 \\
\hline 2 & 22 & 26,20 \\
\hline 3 & 20 & 23,80 \\
\hline 4 & 20 & 23,80 \\
\hline Toplam & 84 & 100,00 \\
\hline Ö̈̆retim türü & $\mathrm{n}$ & $\%$ \\
\hline 1.Öğretim & 42 & 50 \\
\hline 2.Öğretim & 42 & 50 \\
\hline Bölümü isteyerek seçip seçmediği & $\mathrm{n}$ & $\%$ \\
\hline Evet & 66 & 78,57 \\
\hline Hayır & 18 & 21,43 \\
\hline Toplam & 84 & 100,00 \\
\hline Mezun olunca turist rehberliği yapıp yapmayacağ1 & $\mathrm{n}$ & $\%$ \\
\hline Evet & 49 & 58,33 \\
\hline Hayır & 6 & 7,14 \\
\hline Kararsiz & 29 & 34,52 \\
\hline Toplam & 84 & 100,00 \\
\hline
\end{tabular}

Öğrencilerin \%78,57'si (n=66) bölümü isteyerek seçtiklerini, \%21, 43’ü (n=18) bölümü isteyerek seçmediğini belirtmiştir. Öğrencilere yöneltilen mezun olduklarında mesleği yapıp yapmayacakları sorusuna \%58,33 $(n=49)$ evet, \%7,14 $(n=6)$ hayır, \%34,52 (n=29) kararsız şeklinde yanıtlamışlardır. Mesleği yapmayacağını/ kararsız olduğunu belirten öğrencilerin belirttiği nedenler aşağıdaki şekilde sıralanmaktadır:

- Akademik kariyer hedefi

- İşimkânı kaygisı

- YDS'nin geçilememesi/ Yabancı dil sorunu

- Özel sektör korkusu

- Mesleğin kendine uygun olduğunu düşünmemesi

- Turizm alanında farklı bir meslek tercihi

- Kendini yeterince geliştirdiğini düşünmemesi

- Turistlerin profili

- Taban ücret sorunu

- Kadin olmak

- Sektörel sorunlar 
- TUREB' in yeterince destek vermemesi

- İkili ilişkilerdeki iletişim kaygısı

- Mesleğe ilgi duymamasi

- Meslek gereklerinin zorluğu

- Meslek ile ilgili soru işaretleri

Buna göre, turist rehberliği öğrencilerinin çoğunun mezun olduktan sonra mesleği icra etmek istediği, mesleği yapmayacak olanların sayıca az olduğu, kararsız olan öğrencilerin ise akademik kariyer hedefi, iş imkânı kaygısı, YDS'nin geçilememesi/ yabancı dil sorunu şeklinde ifadeler kullandıkları belirlenmiştir.

Tablo 3: Öğrencilerin Turist Rehberliği Eğitimine Yönelik Olumlu Görüşleri

\begin{tabular}{|c|c|c|c|}
\hline Kategoriler & Iffadeler & $\mathrm{n}$ & $\%$ \\
\hline \multirow{3}{*}{ Olumlu Yönler } & Yeterli / Memnun / Verimli / Yerinde / Rahat / Mutlu / İyi / & 36 & 32,44 \\
\hline & Kapsamlı / Olumlu / Zevkli / Faydalı & & \\
\hline & Toplam & 36 & 32,44 \\
\hline \multirow{15}{*}{ Sunulan İmkânlar } & İyi eğitimcilerden eğitim alma imkânı sunulması & 11 & 9,92 \\
\hline & Farklı kültürler tanıma & 6 & 5,40 \\
\hline & Yeni yerler keşfetme & 5 & 4,50 \\
\hline & Tarihi bilgi edinme & 4 & 3,60 \\
\hline & Farklı yabancı diller öğrenme & 3 & 2,70 \\
\hline & Teorik açıdan geniş yelpazede eğitim görme & 2 & 1,80 \\
\hline & İletişim yeterliliği kazanma & 2 & 1,80 \\
\hline & Her alandan fikir sahibi olma & 2 & 1,80 \\
\hline & Farklı disiplinler öğrenme & 2 & 1,80 \\
\hline & Yüksek yaşam kalitesi & 1 & 0,90 \\
\hline & Sürekli öğrenme & 1 & 0,90 \\
\hline & Yeni insanlar tanıma & 1 & 0,90 \\
\hline & Turistik değerleri tanıma & 1 & 0,90 \\
\hline & Yabancı dil eğitimi alma imkânı sunulması & 1 & 0,90 \\
\hline & Toplam & 42 & 37,82 \\
\hline \multirow{7}{*}{ Sağlanan Katkılar } & Bilgi birikimi & 16 & 14,42 \\
\hline & Kişisel gelişim & 8 & 7,22 \\
\hline & Farklı ders içerikleri & 4 & 3,60 \\
\hline & Genel kültür & 3 & 2,70 \\
\hline & Özgüven & 1 & 0,90 \\
\hline & Ülke imajina destek & 1 & 0,90 \\
\hline & Toplam & 33 & 29,74 \\
\hline TOPLAM & & 111 & 100 \\
\hline
\end{tabular}


Araştırmaya katılan turist rehberliği öğrencilerine mesleki eğitime yönelik olumlu düşünceleri sorulmuştur. Görüşmeye katılan öğrencilerin görüşleri \%32,44'ü (n=36) olumlu yönler, \%37,82'si ( $n=42)$ sunulan imkânlar, \%29,74'ü (n=33) sağlanan katk1lar şeklinde kategorilere ayrılmıştır. Kategorilerin tekrarlanma sıklıkları incelendiğinde öğrencilerin en sık tekrarladıkları ifadenin turist rehberliği eğitiminin yeterli / olumlu / kapsamlı / faydalı ( $\mathrm{n}=36$ / \%32,44) olduğu ve rehberlik eğitiminin bilgi birikimi sağladığ1 (n=16 / \%14,42) şeklinde olumlu görüşe sahip olduğu belirlenmiştir. Öğrencilerin olumlu yönler ile ilgili görüşleri arasında; mesleki eğitimin yeterli olması, yerinde olması, mutluluk verici olması, verimli olması, faydalı olması ifadeleri yer almaktadır. Öğrencilerin sunulan imkânlar ile ilgili görüşlerini; iyi eğitimcilerden eğitim alma imkânının sunulması, yeni yerler keşfetme imkânının sunulması, farklı kültürler tanıma imkânı sunulması şeklinde ifade etmişlerdir. Öğrenciler sağlanan katkılar ile ilgili görüşlerini bilgi birikimine katkı sağlaması, kişisel gelişime katkı sağlaması, genel kültür sağlaması şeklinde ifade etmişlerdir.

Tablo 4: Öğrencilerin Turist Rehberliği Eğitimine Yönelik Olumsuz Görüşleri

\begin{tabular}{|c|c|c|c|}
\hline Kategoriler & İfadeler & $\mathrm{n}$ & $\%$ \\
\hline \multirow{5}{*}{ Yabancı dil } & Yabancı dil eğitiminin yetersiz olması & 14 & 20,00 \\
\hline & Yabancı dil eğitiminin YDS ağırlıklı olmaması & 1 & 1,43 \\
\hline & Mesleki yabancı dil- YDS ikilemi & 1 & 1,43 \\
\hline & Her dönem/ sene farklı bir yabancı dil okutmanı ile eğitim görmek & 1 & 1,43 \\
\hline & Toplam & 17 & 24,29 \\
\hline \multirow{6}{*}{ Uygulama } & Eğitimin teorik olarak verilmesi & 20 & 28,56 \\
\hline & Gezi faaliyetlerinin az olması & 6 & 8,56 \\
\hline & Sosyal/ Fiziksel aktivitelerin olmaması & 2 & 2,86 \\
\hline & Staj imkânı yetersizliği & 1 & 1,43 \\
\hline & Sınavların sözlü olması & 1 & 1,43 \\
\hline & Toplam & 30 & 42,84 \\
\hline \multirow{9}{*}{$\begin{array}{l}\text { Ders } \\
\text { İçerikleri }\end{array}$} & Rehberlik ile ilgili derslerin az olması & 3 & 4,29 \\
\hline & Fazla bilgi birikimi gerektirmesi & 2 & 2,86 \\
\hline & Derslerin birbirinin tekrarı niteliğinde olması & 2 & 2,86 \\
\hline & Derslerin ezbere dayalı olması & 1 & 1,43 \\
\hline & Derslerin fazla detaylı olması & 1 & 1,43 \\
\hline & Tarihi derslerin az olması & 1 & 1,43 \\
\hline & Eğitim süresinin kısa olması & 1 & 1,43 \\
\hline & Görsel materyalin az kullanılması & 1 & 1,43 \\
\hline & Toplam & 12 & 17,16 \\
\hline \multirow{3}{*}{ Eğitimciler } & Öğrencilerle tecrübelerini paylaşmamaları & 2 & 2,86 \\
\hline & Yetersiz & 1 & 1,43 \\
\hline & Öğrenci seviyelerinin net olarak belirlenememesi & 1 & 1,43 \\
\hline
\end{tabular}




\begin{tabular}{llrr}
\hline & Özel ilgiye ağırlık verilmemesi & 1 & 1,43 \\
\cline { 2 - 4 } & Toplam & 5 & 7,15 \\
\hline \multirow{3}{*}{$\begin{array}{l}\text { Mesleki } \\
\text { Kaygılar }\end{array}$} & Mesleğin yorucu olması & 4 & 5,70 \\
\cline { 2 - 4 } & Bilgi aktarımının zor olması & 1 & 1,43 \\
\cline { 2 - 4 } & Mesleğe gereken değerin verilmemesi & 1 & 1,43 \\
\cline { 2 - 4 } & Toplam & 6 & 8,56 \\
\hline TOPLAM & & 70 & 100 \\
\hline
\end{tabular}

Araştırmaya katılan turist rehberliği öğrencilerine mesleki eğitime yönelik olumsuz düşüncelerinin neler olduğu sorulmuştur. Araştırmaya katılan öğrencilerin görüşleri $\% 24,29$ yabancı dil, \%42,84 uygulama, \%17,16 ders içerikleri, \%7,15 eğitimciler, \%8,56 mesleki kaygılar şeklinde kategorilere ayrılmıştır. Kategorilerin tekrarlanma sıklıkları incelendiğinde en sık tekrarlanan kategorinin uygulama $(n=30 / \% 42,8)$ olduğu, daha sonra en sık tekrarlanan kategorinin yabancı dil $(\mathrm{n}=17$ / \%24,29) olduğu belirlenmiştir. Öğrencilerin yabancı dil ile ilgili olumsuz görüşleri arasında; yabancı dil eğitiminin YDS ağırlıklı olması, yabancı dil eğitiminin yetersiz olması ve her yıl farklı bir okutman ile eğitim almak ifadeleri yer almaktadır. Öğrencilerin uygulama ile ilgili olumsuz görüşleri arasında; eğitimin teorik olarak verilmesi, gezi faaliyetlerinin az olması, sosyal/ fiziksel aktivitelerin olmaması ifadeleri yer almaktadır. Öğrencilerin ders içerikleri ile ilgili olumsuz görüşleri arasında; rehberlik ile ilgili derslerin az olması, fazla bilgi birikimi gerektirmesi ve derslerin birbirini tekrarlar nitelikte olması ifadeleri yer almaktadır. Öğrencilerin eğitimciler ile ilgili olumsuz görüşleri arasında; öğrencilerle tecrübelerini paylaşmamaları, öğrenci seviyelerinin net olarak belirlenememesi, özel ilgiye ağırlık verilmemesi ifadeleri yer almaktadır. Öğrencilerin mesleki kaygılar ile ilgili olumsuz görüşleri arasında; mesleğin yorucu olması, bilgi aktarımının zor olması ve mesleğe gereken değerin verilmemesi ifadeleri yer almaktadır. Öğrencilerin olumsuz görüşleri arasında en sik tekrarlanan ifadeler öğrencilerin rehberlik eğitiminin teorik olarak verilmesi $(n=20 / \% 28,56)$ ve yabancı dil eğitiminin yetersiz olması ( $\mathrm{n}=14 / \% 20,00)$ şeklindeki ifadelerdir.

Tablo 5: Öğrencilerin Turist Rehberliği Eğitiminin Niteliğinin Artırılmasına Yönelik Önerileri

\begin{tabular}{llll}
\hline Kategoriler & İfadeler & $\mathrm{n}$ & $\%$ \\
\hline & Yabancı dil eğitimine ağırlık verilmesi & 10 & 8,26 \\
\cline { 2 - 4 } Yabancı Dil & Eğitimin İngilizce verilmesi & 7 & 5,78 \\
\cline { 2 - 4 } & Konuşmaya yönelik yabancı dil eğitimi verilmesi & 5 & 4,13 \\
\cline { 2 - 4 } & Hazırlık sınıfı açılması & 2 & 1,65 \\
\cline { 2 - 4 } & Mesleki/ YDS’ye yönelik İngilizce derslerinin ayrılması & 1 & 0,83 \\
\cline { 2 - 4 } Ders İçerikleri & Toplam & 25 & 20,65 \\
\cline { 2 - 4 } & Farklı ders içeriklerinin eklenmesi & 9 & 7,43 \\
\cline { 2 - 3 } & Rehberlik ile ilgili ders çeşitliliğinin artırılması & 6 & 4,96 \\
\cline { 2 - 3 } & Görsel kaynakların kullanılması & 3 & 2,48 \\
\hline
\end{tabular}




\begin{tabular}{|c|c|c|c|}
\hline & Saha içi bilgilendirmelerinin yapılması & 1 & 0,83 \\
\hline & Daha ayrıntılı bilgiler verilmesi & 1 & 0,83 \\
\hline & Bazı derslerin kaldırılması & 1 & 0,83 \\
\hline & Derslerin kolaylaşması & 1 & 0,83 \\
\hline & Toplam & 22 & 18,19 \\
\hline \multirow{8}{*}{ Uygulama } & Gezi düzenlenmesi & 25 & 20,66 \\
\hline & Uygulamalı/ sahada eğitim verilmesi & 22 & 18,18 \\
\hline & Öğrencilerin anlatım/ sunum yapması & 5 & 4,13 \\
\hline & $\begin{array}{l}\text { YDS puanının düşürülmesi/YDS'nin kaldırılması/ uygulamalı/ } \\
\text { sözlü yapılması }\end{array}$ & 5 & 4,13 \\
\hline & Stajın apranti olarak yapılması zorunluluğu getirilmesi & 4 & 3,31 \\
\hline & Konferans/ seminer düzenlenmesi & 2 & 1,65 \\
\hline & Bilgi yarışmaları/ kamp programları düzenlenmesi & 2 & 1,65 \\
\hline & Toplam & 65 & 53,71 \\
\hline \multirow{7}{*}{$\begin{array}{l}\text { Yöneticiler/ } \\
\text { Eğitimciler }\end{array}$} & Sektör- öğrenci dayanışması sağlanması & 3 & 2,48 \\
\hline & Rehberlik eğitiminin sadece lisans düzeyinde verilmesi & 2 & 1,65 \\
\hline & Rehberlik bölümlerinin çoğaltılması & 1 & 0,83 \\
\hline & İş imkânı sağlanması & 1 & 0,83 \\
\hline & Bölüme nitelikli öğrencilerin kabul edilmesi & 1 & 0,83 \\
\hline & Eğitimcilerin kendini güncellemesi & 1 & 0,83 \\
\hline & Toplam & 9 & 7,45 \\
\hline TOPLAM & & 121 & 100 \\
\hline
\end{tabular}

Araştırmaya katılan turist rehberliği öğrencilerine turist rehberliği eğitiminin niteliğinin artması ile ilgili önerileri sorulmuştur. Veri analizleri sonucunda 121 ifade ve 4 kategori belirlenmiştir. Görüşmeye katılan öğrencilerin görüşleri \%20,65'i yabanc1 dil, \%18,19'u ders içerikleri, \%53,71'i uygulama, \%7,45'i yöneticiler / eğitimciler şeklinde kategorilere ayrılmıştır. Kategorilerin tekrarlanma sıklıkları incelendiğinde en sik tekrarlanan kategorinin uygulama $(\mathrm{n}=65 / \% 53,71)$ daha sonra en sik tekrarlanan kategorinin yabancı dil $(\mathrm{n}=25 / \% 20,65)$ olduğu belirlenmiştir. Öğrencilerin yabancı dil ile ilgili görüşleri arasında; yabanc dil eğitimine ağırlık verilmesi, eğitimin İngilizce verilmesi, konuşmaya yönelik yabancı dil eğitimi verilmesi gibi ifadeler yer almaktadır. Öğrencilerin ders içerikleri ile ilgili görüşleri arasında; farklı ders içeriklerinin eklenmesi, rehberlik ile ilgili ders çeşitliliğinin artırılması, görsel kaynakların kullanılması ifadeleri yer almaktadır. Öğrencilerin uygulama ile ilgili görüşleri arasında; gezi düzenlenmesi, uygulamalı / sahada eğitim verilmesi, öğrencilerin anlatım / sunum / proje yapması, stajın apranti olarak yapılması zorunluluğunun getirilmesi, YDS puanının düşürülmesi / YDS'nin kaldırılması / uygulamalı / sözlü yapılması ifadeleri yer almaktadır. Öğrencilerin yöneticiler / eğitimciler ile ilgili görüşleri arasında; sektör-öğrenci dayanışması sağlanması, 
rehberlik eğitiminin sadece lisans düzeyinde verilmesi, eğitimcilerin kendini güncellemesi ifadeleri yer almaktadır. Öğrencilerin turist rehberliği eğitimine yönelik önerileri arasında en sık tekrarlanan ifade gezi düzenlenmesi $(n=25 / \% 20,66)$ ve uygulamalı sahada eğitim verilmesi $(n=22$ / \%18,18) şeklindedir.

Tablo 6: Öğrencilerin Turist Rehberliği Eğitimine Yönelik Yapılabilecek Pratik Uygulamalar ile İlgili Önerileri

\begin{tabular}{|c|c|c|c|}
\hline Kategoriler & İfadeler & $\mathrm{n}$ & $\%$ \\
\hline \multirow{5}{*}{ Uygulama } & Gezi / eğitim gezilerinin düzenlenmesi & 35 & 26,92 \\
\hline & Sahada / uygulamalı eğitim verilmesi & 35 & 26,92 \\
\hline & Öğrencilerin sunum / proje hazırlaması & 13 & 10,00 \\
\hline & Konferans / seminer / etkinlikler düzenlenmesi & 3 & 2,31 \\
\hline & Toplam & 86 & 66,15 \\
\hline \multirow{5}{*}{ Yabancı Dil } & Yabancı dil eğitimine ağırlık verilmesi & 5 & 3,85 \\
\hline & Konuşmaya yönelik yabancı dil eğitimi verilmesi & 4 & 3,08 \\
\hline & Eğitimin İngilizce verilmesi & 3 & 2,31 \\
\hline & Farklı diller öğrenilmesine olanak sağlanması & 2 & 1,54 \\
\hline & Toplam & 14 & 10,78 \\
\hline \multirow{5}{*}{ TUREB } & TUREB'in eğitime destek vermesi & 3 & 2,31 \\
\hline & $\begin{array}{l}\text { TUREB aracılığıyla rehberlerle iletişim kurma imkânı } \\
\text { sunulması }\end{array}$ & 2 & 1,54 \\
\hline & TUREB uygulama gezisi/ sınavı ücretinin düşürülmesi & 1 & 0,77 \\
\hline & $\begin{array}{l}\text { TUREB'in öğrencilere müze/ ören yerlerine ücretsiz giriş hakkı } \\
\text { sağlaması }\end{array}$ & 1 & 0,77 \\
\hline & Toplam & 7 & 5,39 \\
\hline \multirow{2}{*}{ Aprantilik } & Apranti olarak çalışma imkânı sağlanması & 14 & 10,78 \\
\hline & Toplam & 14 & 10,78 \\
\hline \multirow{4}{*}{ Ders İçerikleri } & Ek eğitimler verilmesi & 7 & 5,38 \\
\hline & Meslek ile ilgili teknik araçlar hakkında bilgilendirme yapılması & 1 & 0,77 \\
\hline & Rehberlik bölümü dışındaki derslerin kaldırılması & 1 & 0,77 \\
\hline & Toplam & 9 & 6,92 \\
\hline TOPLAM & & 130 & 100,00 \\
\hline
\end{tabular}

Araştırmaya katılan öğrencilere mesleki eğitime yönelik pratik açıdan ne gibi uygulamalar yapılabileceği sorulmuştur. Araştırmaya katılan öğrencilerin görüşleri \%66.15'i uygulama, \%10.78'i yabanc1 dil, \%5.39'u TUREB, \%10,76's1 aprantilik, \%6,92'si ders içerikleri şeklinde kategorilere ayrılmıştır. Kategorilerin tekrarlanma sıklıkları incelendiğinde en sik tekrarlanan kategorinin uygulama $(n=86 / \% 66,15)$ olduğu, daha sonra en sık tekrarlanan kategorinin yabanc1 dil ( $n=14 / \% 10,78)$ ve aprantilik ( $n=14 / \% 10,78)$ olduğu belirlenmiştir. Öğrencilerin uygulama ile ilgili önerileri arasında; gezi/eğitim gezisi düzenlenmesi, sahada/uygulamalı eğitim 
verilmesi, öğrencilerin sunum/proje hazırlaması, konferans/seminer/etkinlikler düzenlenmesi ifadeleri yer almaktadır. Öğrencilerin yabancı dil ile ilgili önerleri arasında; yabancı dil eğitimine ağırlık verilmesi, konuşmaya yönelik yabancı dil eğitiminin verilmesi, eğitimin İngilizce verilmesi ifadeleri yer almaktadır. Öğrencilerin TUREB ile ilgili önerileri arasında; TUREB'in eğitime destek vermesi, TUREB aracılığıyla rehberlerle iletişim kurma imkânı sunulması, TUREB'in öğrencilere müze/ören yerlerine ücretsiz giriş hakkı sağlaması ifadeleri yer almaktadır. Öğrencilerin Aprantilik ile ilgili önerileri, apranti olarak çalışma imkânı sağlanması olarak belirlenmiştir. Öğrencilerin ders içerikleri ile ilgili önerileri arasında; ek eğitimler verilmesi, rehberlik bölümü dışındaki derslerin kaldırılması, meslek ile ilgili teknik araçlar hakkında bilgilendirme yapılması ifadeleri yer almaktadır. Öğrencilerin pratik uygulamalara yönelik ifadeleri arasında en sık tekrarlanan ifade gezi / eğitim gezilerinin düzenlenmesi $(n=35 / \% 26,92)$, sahada / uygulamalı eğitim verilmesi $(n=35 /$ \%26,92) ve apranti olarak çalışma imkânı sunulması (n=14 / \%10,78) şeklindedir.

Tablo 7: Öğrencilerin Turist Rehberliği Eğitimine Yönelik Fakülte Desteği ile İlgili Görüşleri

\begin{tabular}{|c|c|c|c|}
\hline Kategoriler & İfadeler & $\mathrm{n}$ & $\%$ \\
\hline \multirow{8}{*}{ Olumlu Yönler } & Olumlu/ Yeterli/ İlgili/ Destek verilmesi & 55 & 53,92 \\
\hline & $\begin{array}{l}\text { Konferans/ Seminer/ Etkinlik/ Kariyer günleri düzenlemesi ve } \\
\text { Erasmus programının yapılması }\end{array}$ & 14 & 13,73 \\
\hline & İyi bir eğitim verilmesi & 8 & 7,85 \\
\hline & Gezi düzenlenmesi & 6 & 5,88 \\
\hline & Staj/ iş bulma sürecinde kolaylık sağlaması & 5 & 4,90 \\
\hline & Eğitimci- öğrenci iletişiminin iyi olması & 3 & 2,94 \\
\hline & Daha fazla destek beklentisi & 2 & 1,96 \\
\hline & Toplam & 93 & 91,18 \\
\hline Olumsuz Yönler & Yetersiz & 9 & 8,82 \\
\hline TOPLAM & & 102 & 100,00 \\
\hline
\end{tabular}

Araştırmaya katılan öğrencilere mesleki eğitimde fakülte desteği düşünceleri sorulmuştur. Görüşmeye katılan öğrencilerin \%91,18'i olumlu, \%8,82'si olumsuz yönde görüş bildirmişlerdir. Öğrencilerin olumlu görüşleri arasında fakültenin ilgili, yeterli, destekleyici olması ifadeleri yer almaktadır. Öğrenciler olumsuz görüşlerini mesleki eğitimde fakülte desteğinin yetersiz olduğu şeklinde ifade etmiştir. Kategorilerin tekrarlanma sıklıkları incelendiğinde en sık tekrarlanan ifadelerden yola çıkarak fakülte desteğinin olumu/yeterli olduğu $(n=55 / \% 53,92)$ ve fakültenin konferans/seminer/kongre/etkinlik/kariyer günleri/Erasmus programı düzenlemesi ( $n=14$ / \%13,73) yönünde görüşlere sahip oldukları belirlenmiştir. 
Tablo 8: Öğrencilerin Turist Rehberliği Eğitimine Yönelik Fakülte Desteği ile İlgili Önerileri

\begin{tabular}{|c|c|c|c|}
\hline Kategoriler & İfadeler & $\mathrm{n}$ & $\%$ \\
\hline \multirow{8}{*}{ Uygulama } & Gezi düzenlenmesi & 21 & 20,19 \\
\hline & Konferans/ Seminer/ Kongre/Etkinlik düzenlenmesi & 8 & 7,69 \\
\hline & Öğrencilerin rehberlerle iletişim kurmasının sağlanması & 6 & 5,77 \\
\hline & Deneyim kazanılmasına yardımcı olunması & 5 & 4,82 \\
\hline & Öğrencilerin sunum/ proje hazırlaması & 5 & 4,82 \\
\hline & Aprantilik/ Nitelikli staj imkânı sunulması & 4 & 3,85 \\
\hline & Görsel öğelerin kullanılması/ artırılması & 3 & 2,88 \\
\hline & Toplam & 52 & 50,02 \\
\hline \multirow{4}{*}{ Ders İçerikleri } & Farklı ders içeriklerinin eklenmesi ve zamana yayılması & 10 & 9,62 \\
\hline & Nitelikli eğitim verilmesi & 1 & 0,96 \\
\hline & $\begin{array}{l}\text { Okul binası içerisine ders içerikleri ile ilgili özel köşeler } \\
\text { oluşturulması }\end{array}$ & 1 & 0,96 \\
\hline & Toplam & 12 & 11,54 \\
\hline \multirow{3}{*}{ Yabancı Dil } & Yabancı dil eğitimine ağırlık verilmesi & 12 & 11,54 \\
\hline & Konuşmaya yönelik yabancı dil dersleri verilmesi & 2 & 1,92 \\
\hline & Toplam & 14 & 13,46 \\
\hline \multirow{3}{*}{ Ek Eğitimler } & Erasmus programı ve yurtdışı eğitim programlarının açılması & 5 & 4,82 \\
\hline & Ek eğitim programları ve özel kurslar açılması & 3 & 2,88 \\
\hline & Toplam & 8 & 7,7 \\
\hline \multirow{10}{*}{ İmkân / Destek } & Kariyer günlerinde daha fazla acenta bulunması & 3 & 2,88 \\
\hline & Daha fazla ilgi ve imkân sunulması & 2 & 1,92 \\
\hline & TUREB uygulama gezisine maddi destek sağlanması & 2 & 1,92 \\
\hline & Devlet ve burs desteği sağlanması & 2 & 1,92 \\
\hline & Sahada destek sağlanması & 2 & 1,92 \\
\hline & $\begin{array}{l}\text { Öğrencilerle/ diğer fakültelerdeki rehberlik öğrencileri ile iletişimin } \\
\text { artırılması }\end{array}$ & 2 & 1,92 \\
\hline & Kaynak kitap ve kütüphane desteği sağlanması & 2 & 1,92 \\
\hline & İş imkânı sağlanması & 2 & 1,92 \\
\hline & Uzmanlaşmaya destek verilmesi & 1 & 0,96 \\
\hline & Toplam & 18 & 17,28 \\
\hline TOPLAM & & 104 & 100,00 \\
\hline
\end{tabular}

Araştırmaya katılan öğrencilere turist rehberliği eğitimine yönelik fakülte desteği ile ilgili önerileri sorulmuştur. Öğrencilerin görüşleri \%52,02'si uygulama, \%11,54'ü ders içerikleri, \%13,46'sı yabancı dil, \%7,7'si ek eğitimler, \%17,28'i imkân/ destek ile ilgili öneriler şeklinde kategorilere ayrılmıştır. Kategorilerin tekrarlanma sıklıkları incelendiğinde en sık tekrarlanan kategorinin uygulama sonrakinin ise imkân / destek şeklindeki kategoriler olduğu belirlenmiştir. Öğrencilerin uygulama ile ilgili önerileri 
arasında; gezi düzenlenmesi, konferans/seminer/etkinlik/kongre düzenlenmesi, öğrencilerle rehberlerin iletişim kurmasının sağlanması, öğrencilerin proje/sunum hazırlaması ifadeleri yer almaktadır. Öğrencilerin ders içerikleri ile ilgili önerileri arasında; farklı ders içeriklerinin eklenmesi, nitelikli eğitim verilmesi, okul binası içerisinde ders içerikleri ile ilgili özel köşeler oluşturulması ifadeleri yer almaktadır. Öğrencilerin yabancı dil ile ilgili önerileri arasında; yabancı dil eğitimine ağırlık verilmesi ve konuşmaya yönelik dil eğitiminin verilmesi ifadeleri yer almaktadır. Öğrencilerin ek eğitim ile ilgili önerileri arasında; Erasmus programı ve yurtdışı eğitim programlarının açılması, ek eğitim programları ve özel kurslar açılması ifadeleri yer almaktadır. Öğrencilerin imkân/ destek ile ilgili önerileri arasında; kariyer günlerinde daha fazla acenta bulunması, TUREB uygulama gezisine maddi destek sağlaması, kaynak kitap ve kütüphane desteği sağlanması, sahada destek sağlanması ifadeleri yer almaktadır. Öğrencilerin fakülte desteğine yönelik önerileri arasında en sık tekrarlanan ifade gezi düzenlenmesi $(n=21 / 21,19)$ ve yabancı dil eğitimine ağırlık verilmesidir ( $\mathrm{n}=12 / \% 11,54)$.

Tablo 9: Öğrencilerin Turist Rehberliği Eğitimine Yönelik TUREB Desteği ile İlgili Görüşleri

\begin{tabular}{|c|c|c|c|}
\hline Kategoriler & İfadeler & $\mathrm{n}$ & $\%$ \\
\hline \multirow{3}{*}{$\begin{array}{l}\text { TUREB Uygulama } \\
\text { Gezisi/ Sinavi }\end{array}$} & TUREB uygulama gezisi/sınavı ücretinin düşürülmesi & 14 & 17,95 \\
\hline & Uygulama gezisi kontenjanı artırılmalı & 1 & 1,28 \\
\hline & Toplam & 15 & 19,23 \\
\hline \multirow[t]{3}{*}{ Olumlu } & Olumlu/Yeterli/ Memnun/Yol gösterici bir niteliğe sahip & 18 & 23,08 \\
\hline & Yetersiz/Olumsuz/Zayıf & 21 & 26,93 \\
\hline & TUREB desteği ile ilgili bilgiye sahip değil & 2 & 2,56 \\
\hline \multirow[t]{8}{*}{ Olumsuz } & Staja destek vermiyor & 1 & 1,28 \\
\hline & İş imkânı sunmuyor & 1 & 1,28 \\
\hline & Toplam & 25 & 32,05 \\
\hline & Ek gezi & 4 & 5,14 \\
\hline & Daha fazla destek & 3 & 3,85 \\
\hline & Kendini tanıtıp öğrencilerle iletişim kurulması & 3 & 3,85 \\
\hline & Olumlu beklenti & 2 & 2,56 \\
\hline & $\begin{array}{l}\text { Müze/Ören yeri girişlerinin rehberlik öğrencilerine ücretsiz } \\
\text { olması }\end{array}$ & 2 & 2,56 \\
\hline \multirow[t]{7}{*}{ Beklenti } & Daha fazla imkân & 1 & 1,28 \\
\hline & Öğrencilerle empati kurulması & 1 & 1,28 \\
\hline & Yabancı dil sınavı ikileminin kaldırılması & 1 & 1,28 \\
\hline & Uygulama gezisi kadrosunun genişletilmesi beklentisi & 1 & 1,28 \\
\hline & 6 aylık sertifika programlarının kaldırılması beklentisi & 1 & 1,28 \\
\hline & 6 aylık sertifika programlarının açılması beklentisi & 1 & 1,28 \\
\hline & Toplam & 20 & 25,64 \\
\hline \multicolumn{2}{|l|}{ TOPLAM } & 78 & 100,00 \\
\hline
\end{tabular}


Araştırmaya katılan öğrencilere TUREB desteği ile ilgili düşünceleri sorulmuştur. Öğrencilerin görüşleri \%19,23'ü TUREB uygulama gezisi / sinavı, \%23,08'i olumlu, \%32, 05'i olumsuz, \%25,64'ü beklentiler şeklinde kategorilere ayrılmıştır. Kategorilerin tekrarlanma sıklıkları incelendiğinde en sık tekrarlanan kategorinin olumsuz ve beklentiler kategorisi olduğu belirlenmiştir. Öğrencilerin TUREB uygulama gezisi / sınavı ile ilgili görüşleri arasında; TUREB uygulama gezisi/ sınavı ücretinin düşürülmesi ve uygulama gezisi kontenjanının artırılması ifadeleri yer almaktadır. Öğrenciler olumlu yöndeki görüşlerini TUREB desteğinin yeterli, olumlu, yol gösterici olarak belirtmişlerdir. Öğrenciler olumsuz yöndeki görüşlerini TUREB desteğinin yetersiz, olumsuz ve zayıf olduğunu, TUREB desteği ile ilgili bilgiye sahip olmadıklarını belirtmiştir. Öğrencilerin beklentileri ile ilgili görüşleri arasında ek gezi yapılması, eğitime daha fazla destek vermesi, kendini öğrencilere tanıtıp öğrencilerle iletişim kurması gerektiğini, müze/ ören yerleri girişlerinin turist rehberliği öğrencilerine ücretsiz olması ifadeleri yer almaktadır. Öğrencilerin TUREB desteğine yönelik görüşleri arasında en sık tekrarlanan ifadeler yetersiz/ zayıf ( $n=21$ / \%26,93), olumlu/ yeterli ( $n=18$ / \%23,08), TUREB uygulama gezisi/ sınavı ücretinin düşürülmesi ( $\mathrm{n}=14$ / \%17,95) şeklindeki ifadelerdir.

Tablo 10: Öğrencilerin Turist Rehberliği Eğitimine Yönelik TUREB Desteği ile İlgili Önerileri

\begin{tabular}{|c|c|c|c|}
\hline Kategoriler & İfadeler & $\mathrm{n}$ & $\%$ \\
\hline \multirow{4}{*}{ Ücret } & $\begin{array}{l}\text { TUREB } \quad \text { uygulama } \\
\text { düşürülmesi/taksitlendirilmesi }\end{array}$ & 29 & 31,51 \\
\hline & Müze/ören yerlerine rehberlik öğrencilerinin ücretsiz giriş & 9 & 9,78 \\
\hline & $\begin{array}{l}\text { Uygulama gezisinin ücretsiz olması / yabancı dil sınavından belli bir } \\
\text { puanı geçen öğrencilere ücretsiz olması* }\end{array}$ & 1 & 1,09 \\
\hline & Toplam & 39 & 42,38 \\
\hline \multirow{13}{*}{$\begin{array}{l}\text { Ek Uygulamalar/ } \\
\text { Eğitimler }\end{array}$} & Ek geziler ve kurslar düzenlemesi & 13 & 14,13 \\
\hline & 6 aylık sertifika programlarının kaldırılması & 5 & 5,43 \\
\hline & Konferans/ seminer/ kongre düzenlemesi & 4 & 4,35 \\
\hline & Aprantilik firsatının verilmesi & 4 & 4,35 \\
\hline & Uzmanlaşma eğitimleri açması & 3 & 3,26 \\
\hline & Farklı faaliyetler/ yenilikler gerçekleştirmesi & 2 & 2,17 \\
\hline & Ĕ̆itimi daha fazla önemsemesi & 1 & 1,09 \\
\hline & Kaliteli uygulamalar getirmeli & 1 & 1,09 \\
\hline & Rehberlik öğrencilerine özel tanıtım araçları oluşturmalı & 1 & 1,09 \\
\hline & $\begin{array}{l}\text { TUREB dil sınavı için internet üzerinden örnek soru/ konu anlatımı } \\
\text { imkânı sunmalı }\end{array}$ & 1 & 1,09 \\
\hline & TUREB sınav merkezlerini çoğaltmalı & 1 & 1,09 \\
\hline & Türkçe rehberliği önlemeli/ Sadece belli bölgelerde izin vermeli* & 1 & 1,09 \\
\hline & Toplam & 37 & 40,23 \\
\hline \multirow{2}{*}{ Destek } & Daha fazla destek vermesi & 7 & 7,60 \\
\hline & Staj ve yabancı dil konusunda destek vermeli & 5 & 5,43 \\
\hline
\end{tabular}




\begin{tabular}{|c|c|c|c|}
\hline & Tur otobüslerini rehberlik öğrencilerinin kullanımına sunmalı* & 1 & 1,09 \\
\hline & Rehber- öğrenci iletişimi sağlaması & 1 & 1,09 \\
\hline & Öğrencilere ılımlı bir yaklaşım içerisinde olmalı & 1 & 1,09 \\
\hline & $\begin{array}{l}\text { YDS puanının düşürülmesi/ sınavın iki parça halinde yapılmasına } \\
\text { katkı sağlaması }\end{array}$ & 1 & 1,09 \\
\hline & Toplam & 16 & 17,39 \\
\hline TOPLAM & & 92 & 100,00 \\
\hline
\end{tabular}

Araştırmaya katılan öğrencilere turist rehberliği eğitiminde TUREB desteği ile ilgili önerileri sorulmuştur. Öğrencilerin önerileri \%42,38'i ücret, \%40,23'ü ek uygulamalar/ eğitimler, \%17, 39’u destek şeklindeki kategorilere ayrılmıştır. Buna göre en sık tekrarlanan kategori ücret ve ek uygulamalar/eğitimlerdir. Öğrencilerin ücret ile ilgili önerileri arasında; TUREB uygulama gezisi/ sinavı ücretinin düşürülmesi/ taksitlendirilmesi, müze/ ören yerlerine rehberlik öğrencilerinin ücretsiz giriş yapabilmesi, uygulama gezisinin ücretsiz olması/ yabancı dil sinavından belli bir puanı geçen öğrencilere ücretsiz olması ifadeleri yer almaktadır. Öğrencilerin ek uygulamalar/ eğitimler ile ilgili önerileri arasında; ek geziler ve kurslar düzenlenmesi, konferans/ seminer/ kongre düzenlenmesi, farklı faaliyetler/ yenilikler düzenlenmesi ifadeleri yer almaktadır. Öğrencilerin destek ile ilgili önerileri arasında; TUREB'in öğrencilere daha fazla destek vermesi, staj ve yabancı dil konusunda destek vermesi, rehber- öğrenci iletişimini sağlaması, tur otobüslerini öğrencilerin kullanımına sunması ifadeleri yer almaktadır. Öğrencilerin TUREB desteğine yönelik önerileri arasında en sık tekrarlanan ifade uygulama gezisi/ sınavı ücretinin düşürülmesi/ taksitlendirilmesi ( $n=29$ / \%31, 51) ve ek geziler/ kurslar düzenlenmesidir ( $n=13$ / \%14, 13).

Tablo 11: Öğrencilerin Turist Rehberliği Eğitimine Yönelik Fakülte ile İlgili Beklentileri

\begin{tabular}{|c|c|c|c|}
\hline Kategoriler & İfadeler & $\mathrm{n}$ & $\%$ \\
\hline \multirow{8}{*}{ Uygulama } & Gezi düzenlemesi & 19 & 20,22 \\
\hline & Konferans/ Seminer/ Etkinlik düzenlemesi & 14 & 14,90 \\
\hline & Uygulamalı/ sahada eğitim & 9 & 9,58 \\
\hline & Öğrencilerin sunum/ proje hazırlaması & 3 & 3,19 \\
\hline & Dil laboratuvarı açılması & 1 & 1,06 \\
\hline & Sosyal imkânlar sunulması & 1 & 1,06 \\
\hline & Sinema salonu & 1 & 1,06 \\
\hline & Toplam & 48 & 51,07 \\
\hline \multirow{5}{*}{ Yabancı Dil } & Nitelikli bir yabancı dil eğitimi & 10 & 10,64 \\
\hline & Eğitimin İngilizce olması & 2 & 2,13 \\
\hline & Farklı yabancı diller eklenmesi & 2 & 2,13 \\
\hline & Yabancı dil eğitiminin yabancı eğitimciler tarafından verilmesi & 1 & 1,06 \\
\hline & 4 yıl boyunca aynı eğitimci ile yabancı dil eğitimi & 1 & 1,06 \\
\hline
\end{tabular}




\begin{tabular}{|c|c|c|c|}
\hline & Konuşma ağırlıklı yabancı dil eğitimi & 1 & 1,06 \\
\hline & Toplam & 17 & 18,08 \\
\hline \multirow{4}{*}{ Ders İçerikleri } & Ders içeriklerinin çeşitlendirilmesi & 8 & 8,52 \\
\hline & Daha iyi bir eğitim & 4 & 4,26 \\
\hline & Ders saatlerinin daha geç başlaması & 3 & 3,19 \\
\hline & Toplam & 15 & 15,97 \\
\hline \multirow{5}{*}{ İletişim/ Tanıtım } & $\begin{array}{l}\text { Diğer fakültelerdeki öğrencilerle ve rehberlerle iletişim kurma imkânı } \\
\text { sunması }\end{array}$ & 2 & 2,13 \\
\hline & Fakültenin tanıtımının yapılması & 1 & 1,06 \\
\hline & Öğrencilere daha fazla bilgilendirme yapılması & 1 & 1,06 \\
\hline & Öneri ve isteklerin dikkate alınması & 1 & 1,06 \\
\hline & Toplam & 5 & 5,31 \\
\hline \multirow{4}{*}{ Destek } & $\begin{array}{l}\text { Öğrencilere maddi destek verilmesi/ mezuniyet sonrası da öğrencilerin } \\
\text { desteklenmesi }\end{array}$ & 4 & 4,26 \\
\hline & Bölümün gelişmesi/ puanın yükseltilmesi & 3 & 3,19 \\
\hline & 4. sınıf öğrencilerine devam zorunluluğunda esneklik tanınması & 2 & 2,13 \\
\hline & Toplam & 9 & 9,58 \\
\hline TOPLAM & & 94 & 100,00 \\
\hline
\end{tabular}

Araştırmaya katılan öğrencilere turist rehberliği eğitiminde fakülte desteğine yönelik beklentileri sorulmuştur. Öğrencilerin \%51,07'si uygulama, \%18,08'i yabancı dil, \%15,97'si ders içerikleri, \%5,31'i iletişim/ tanıtım, \%9,58'i destek ile ilgili beklentilerinin bulunduğu belirlenmiştir. Öğrencilerin uygulama ile ilgili beklentileri arasında; gezi düzenlenmesi, konferans/ seminer/ etkinlik düzenlenmesi, uygulamalı sahada eğitim verilmesi ifadeleri yer almaktadır. Öğrencilerin yabancı dil ile ilgili beklentileri arasında; nitelikli bir yabancı dil eğitimi verilmesi, eğitimin İngilizce verilmesi, farklı yabancı diller eklenmesi ifadeleri yer almaktadır. Öğrencilerin ders içerikleri ile ilgili beklentileri arasında; ders içeriklerinin çeşitlendirilmesi, daha iyi bir eğitim verilmesi, ders saatlerinin daha geç başlaması ifadeleri yer almaktadır. Öğrencilerin iletişim/ tanıtım ile ilgili beklentileri arasında; diğer fakültelerdeki öğrencilerle ve rehberlerle iletişim kurma imkânı sunması, öğrencilere daha fazla bilgilendirme yapılması, öneri ve isteklerin dikkate alınması, fakültenin tanıtımının yapılması ifadeleri yer almaktadır. Öğrencilerin destek ile ilgili beklentileri arasında öğrencilere maddi destek verilmesi/ mezuniyet sonrası da öğrencilerin desteklenmesi, bölümün gelişip puanının yükseltilmesi, 4 . Sınıf öğrencilerine devam zorunluluğunda esneklik sağlanması ifadeleri yer almaktadır. İfadelerin tekrarlanma sıklıkları incelendiğinde en sik tekrarlanan ifadenin öğrencilerin fakülteye yönelik gezi düzenlenmesi (n=19 / \%20,22) ve konferans/ seminer/ etkinlik düzenlenmesi (n=14 / $\% 14,90)$ şeklinde önerilerde bulundukları belirlenmiştir. 
Tablo 12: Öğrencilerin Turist Rehberliği Eğitimine Yönelik TUREB ile İlgili Beklentileri

\begin{tabular}{|c|c|c|c|}
\hline Kategoriler & İfadeler & $\mathrm{n}$ & $\%$ \\
\hline \multirow{3}{*}{ Ücret } & $\begin{array}{l}\text { TUREB uygulama gezisi/ sınavının ücretinin } \\
\text { düşürülmesi/kaldırılması/ sabit kalması }\end{array}$ & 26 & 27,66 \\
\hline & $\begin{array}{l}\text { Müze/ören yeri girişlerinin rehberlik öğrencilerine ücretsiz } \\
\text { olması }\end{array}$ & 7 & 7,45 \\
\hline & Toplam & 33 & 35,11 \\
\hline \multirow{13}{*}{$\begin{array}{l}\text { Ek } \\
\text { Eğitimler }\end{array}$} & Ek geziler/eğitimler düzenlemeli & 8 & 8,52 \\
\hline & Konferans/ Seminer/ Etkinlik düzenlemeli & 3 & 3,19 \\
\hline & Öğrencilere burs imkânı sunması & 2 & 2,13 \\
\hline & TUREB yabancı dil sınavının farklı illerde de yapılması & 1 & 1,06 \\
\hline & İlköğretimden itibaren turizm dersleri verilmesini sağlamalı & 1 & 1,06 \\
\hline & Uygulama gezisi kontenjanını düşürmeli & 1 & 1,06 \\
\hline & Yabancı dil eğitimi vermeli & 1 & 1,06 \\
\hline & Her bölge için uygulama gezisi açmalı & 1 & 1,06 \\
\hline & $\begin{array}{l}\text { Önlisans eğitiminin eksiklerinin giderilmesine yardımcı } \\
\text { olmalı }\end{array}$ & 1 & 1,06 \\
\hline & Tezsiz yüksek lisansın kaldırılmasına destek vermeli & 1 & 1,06 \\
\hline & $\begin{array}{l}\text { Konu anlatımı/örnek soru yayınlayarak TUREB yabancı dil } \\
\text { sınavına yardımcı olmalı }\end{array}$ & 1 & 1,06 \\
\hline & İş̧ imkânı ve koşullarını iyileştirmeli & 1 & 1,06 \\
\hline & Toplam & 22 & 23,38 \\
\hline \multirow{5}{*}{ Destek } & Daha fazla destek vermeli & 14 & 14,90 \\
\hline & Öğrencilerle iletişim kurmalı & 16 & 17,02 \\
\hline & Eğitime/ Staja/Aprantiliğe destek vermeli & 8 & 8,52 \\
\hline & Mesleki tanıtım yapmalı & 1 & 1,06 \\
\hline & Toplam & 39 & 41,5 \\
\hline TOPLAM & & 94 & 100,00 \\
\hline
\end{tabular}

Araştırmaya katılan öğrencilere turist rehberliği eğitiminde TUREB'e yönelik beklentileri sorulmuştur. Öğrencilerin \%35,11'i ücret, \%23,38'i ek uygulamalar/ eğitimler, \%41,5'i destek ile ilgili görüş bildirmişlerdir. Öğrencilerin ücret ile ilgili beklentileri arasında; TUREB uygulama gezisi/ sınavının ücretinin düşürülmesi/ kaldırılması/ sabit kalması, müze/ ören yeri girişlerinin rehberlik öğrencilerine ücretsiz olması ifadeleri yer almaktadır. Öğrencilerin ek uygulamalar/ eğitimler ile ilgili beklentileri arasında; ek geziler/ eğitimler düzenlenmesi, konferans/ seminer/ etkinlik düzenlenmesi, öğrencilere burs imkânı sunulması, ilköğretimden itibaren turizm derslerinin verilmesi, iş imkânı ve koşullarının iyileştirilmesi ifadeleri yer almaktadır. Öğrencilerin destek ile ilgili beklentileri arasında; TUREB'in öğrencilerle iletişim kurması, daha fazla destek vermesi, eğitime/ staja aprantiliğe destek vermesi ifadeleri yer almaktadır. İ́adelerin tekrarlanma sıklıkları incelendiğinde en sık tekrarlanan 
ifadelerin TUREB uygulama gezisi/ sınavının ücretinin düşürülmesi/ kaldırılmasi/ sabit kalması ( $n=26 / \% 27,66)$, öğrencilerle iletişim kurması $(n=16 / \% 17,02)$ ve eğitime daha fazla destek vermesi $(n=14 / \% 14,90)$ şeklinde beklentiler olduğu belirlenmiştir.

\section{TARTIŞMA, SONUÇ ve ÖNERİLER}

Turist rehberliği eğitimi, nitelikli ve donanımlı rehberler yetişmesini sağlamaktadır. Turist rehberliği eğitiminin fakültenin yanı sıra meslek kuruluşlarının da desteği ve katkılarıyla daha kaliteli, verimli ve nitelikli bir şekilde gerçekleştirileceği göz ardı edilmemelidir. $\mathrm{Bu}$ nedenle yapılan araştırmada öğrencilere rehberlik eğitiminde fakülteleri ve TUREB'e yönelik düşünce, beklenti ve önerileri sorulmuştur. Öğrencilerin verdikleri cevaplar içerik analizine tabi tutularak veri analizi ve yorumlamaları gerçekleştirilmiştir. İçerik ve veri analizleri sonucunda öğrencilerin turist rehberliği eğitimine yönelik görüşlerini içeren 17 farklı kategori belirlenmiştir. Öğrencilerin görüşlerine göre oluşturulan kategorilerden en sik kullanılan kategorilerin uygulama, yabancı dil ve ders içerikleri olduğu belirlenmiştir. Öğrencilerin görüşlerinden yola çıkarak en sık tekrarlanan ifadelerin; fakülte desteğinin yeterli olduğu $(n=55)$, turist rehberliği eğitimine yönelik düşüncelerinin olumlu olduğu $(n=36)$, sahada/ uygulamalı eğitim verilerek gezilerin düzenlenmesi gerektiği ( $n=35)$, TUREB'in uygulama gezisi/ sınavının ücretinin düşürülmesi önerisi $(n=29)$ yer almaktadır. Bu verilerden hareketle öğrencilerin turist rehberliği eğitiminin ve fakülte desteğinin yeterli olduğu görüşlerine sahip oldukları belirlenmiştir. Öğrencilerin turist rehberliği eğitiminde fakülte ve TUREB'e yönelik uygulama açısından bir beklenti içerisinde olduğu sonucuna ulaşılmıştır.

Elde edilen veriler 1şığında, turist rehberliği eğitimi alan öğrencilerin, eğitimin yeterli olduğu ve bilgi birikimi sağladığı yönünde olumlu görüş bildirdikleri belirlenmiştir. Araştırmanın bu sonucu Karaman vd., (2012)' nin elde ettiği sonuçla paralellik göstermemekte ancak Erdem ve Etiz (2012)'in elde ettiği sonuçla paralellik göstermektedir. Olumsuz açıdan ise eğitimin teorik açıdan verilmesi ve yabancı dil eğitiminin yetersiz olması görüşlerine sahip oldukları belirlenmiştir. Öğrencilerin, turist rehberliği eğitiminin niteliğinin uygulamalı/ sahada eğitim verilmesi ve geziler düzenlenmesi gibi pratik uygulamalarla sağlanacağı görüşlerine sahip oldukları saptanmıştır. Araştırmanın bu sonucu Esen ve Gülmez (2018a) ve Aydın ve Korkmaz (2018)'in sonuçlarıyla paralellik göstermektedir. Öğrencilerin, turist rehberliği eğitiminde fakülte desteğinin yeterli olduğu, çeşitli etkinliklerle bu desteğin pekiştirildiğini ancak geziler düzenlenerek ve yabancı dil eğitimine ağırlık verilerek eğitimin daha nitelikli olacağı yönünde görüşlere sahip oldukları belirlenmiştir. Öğrencilerin turist rehberliği eğitiminde TUREB desteğine yönelik TUREB'in yol gösterici, olumlu ve yeterli bir niteliğe sahip olduğu şeklinde olumlu görüşlere sahip olduğu belirlenmiştir. Olumsuz açıdan ise TUREB desteğinin yetersiz kaldı̆̆ı, uygulama gezisinin ve TUREB dil sınavının ücretinin öğrenci bütçesine uygun olmadığ1 görüşlerine sahip oldukları belirlenmiştir. Öğrencilerin, TUREB’in, TUREB uygulama gezisi/ sınavının ücretini düşürerek veya taksitlendirilerek, ek geziler/ kurslar düzenleyerek turist rehberliği eğitimine katkı sağlayabileceği yönünde 
önerilerde bulundukları belirlenmiştir. Yapılan alanyazın taraması sonucunda diğer çalışmalarda öğrencilerin TUREB' e yönelik görüş, beklenti ve önerilerine yer verilmediği saptanmıştır. Bu nedenle gerçekleştirilen araştırmanın alanyazına önemli bir katk1 sunduğu düşünülmektedir. Öğrencilerin mesleki eğitime yönelik görüşlerinin belirlenmesinin amaçlandığı bu araştırma genel çerçeve itibariyle alanyazında yer alan çalışmalarla paralellik göstermektedir. Sonuç olarak, turist rehberliği eğitimi alan öğrenciler, olumlu düşüncelere sahiptirler. Eğitimin niteliğinin artması için fakültenin ve TUREB'in gerek ders içerikleri ve yabancı dil eğitimi gerekse eğitimin uygulamalar ile desteklenmesinin gerektiği sonucuna ulaşılmıştır.

Öğrencilerin TUREB desteğine yönelik önerileri arasında tekrarlanma sıklığ1 az olmasına rağmen dikkat çekici öneriler tespit edilmiştir. Önerilerden ilki öğrencilerin uygulama gezisinin ücretsiz olması veya yabancı dil sınavını geçen öğrencilere ücretsiz olması yönündedir. Bu öneriden anlaşılacağı üzere öğrencilerin TUREB uygulama gezisi ücretine yönelik olumsuz düşünceleri olduğu sonucuna ulaşılmıştır. İkinci öneri TUREB'in Türkçe rehberliği engellemesi gerektiği veya sadece belli bölgelerde izin verilmesi şeklindedir. Bu öneriden hareketle öğrencilerin Türkçe rehberliğe sıcak bakmadıkları veya belli sınırlamalar dâhilinde izin verilmesi gerektiğini düşünmektedirler. Üçüncü öneri ise TUREB'in tur otobüslerini rehberlik öğrencilerinin kullanımına sunması şeklindedir. Bu öneriden hareketle öğrencilerin rehberlik mesleğini deneyimleyebilmek konusunda istekli oldukları bu deneyimi yaşayabilmek için ise TUREB'in imkânlarından faydalanmak istedikleri sonucuna ulaşılmıştır.

Her araştırmada olduğu gibi bu çalışmanın da birtakım sınırlılıkları bulunmaktadır. Araştırma Balıkesir Üniversitesi Turizm Rehberliği lisans öğrencileri ile sınırlıdır. Bundan sonraki çalışmalarda farklı eğitim kademelerinden öğrencilerin, akademisyenlerin ve mesleği aktif olarak yürüten turist rehberlerinin de görüşleri dâhil edilebilir. Ayrıca birden fazla şehir ya da fakültede araştırma kapsamına alınabilir ve çeşitli karşılaştırmalar da ilave edilebilir.

Hakem Değerlendirmesi: Dıs, bağmsız.

Teşekkür: Katkılarından dolayı hakemlere teşekkür ederiz.

Destek Bilgisi: Herhangi bir kurum ve/veya kuruluştan destek alınmamıştır.

Çıkar Çatışması: Çıkar çatışması yoktur.

Etik Onayı: Bu çalışmanın tüm hazırlanma süreçlerinde etik kurallara riayet edildiğini yazar(lar) beyan eder. Aksi bir durumun tespiti halinde Güncel Turizm Araştırmaları
Dergisi'nin hiçbir sorumluluğu olmayıp, tüm sorumluluk makale yazar(lar)ına aittir.

Bilgilendirilmiş Onam Formu: Tüm taraflar kendi rızaları ile çalışmaya dâhil olmuşlardır.

Etik Kurul Onayı: Çalışma verileri 2020 yılı öncesinde toplanarak tamamlanmıştır.

Araştırmacıların Katkı Oranı: 1. yazar katkı oranı: $\% 50$; 2 . yazar katk1 oranı: $\% 50$.

Veri Kullanılabilirlik Beyanı: Araştırma verileri paylaşılmamıştır. 


\section{KAYNAKÇA}

Altunışık, R., Coşkun, R., Bayraktaroğlu, S. ve Yıldırım, E. (2015). Sosyal Bilimlerde Araştırma Yöntemleri. Adapazarı: Sakarya Kitabevi.

Aydın, N. ve Korkmaz, H. (2018). Turizm rehberliği eğitimi alan öğrencilerin staj uygulamalarına yönelik tutumlarının belirlenmesi: Balıkesir Üniversitesi Örneği, Necdet Hacioğlu vd. (Ed.), içinde Turizm/ Turist Rehberliği Eğitimi (s. 181- 189). Ankara: Detay.

Aymankuy, Y., Aymankuy, Ş., Tetik, N. ve Girgin, G. K. (2013). Lisans düzeyinde turizm eğitimindeki staj uygulamasına öğrenci ve akademisyenlerin bakışları (Balıkesir Üniversitesi Turizm ve Otelcilik Yüksekokulu'nda Bir Uygulama). International Journal of Human Sciences, 10(1), 101- 128.

Coşkun, R., Altunışık, R. ve Yıldırım, E. (2017). Sosyal Bilimlerde Araştırma Yöntemleri: SPSS Uygulamalı. (9. Baskı). Sakarya: Sakarya Yayıncılık.

Değirmencioğlu, A. Ö. (1998). Türkiye' de Turizm Rehberliği Eğitimine Bir Yaklaşım. Yüksek Lisans Tezi. Gazi Üniversitesi Sosyal Bilimler Enstitüsü, Turizm Eğitimi Anabilim Dalı, Ankara.

Eker, N. (2015). Profesyonel Turist Rehberleri Bakış Açısıyla Turizm Rehberliği Eğitim Müfredatlarının Uygulama Yeterliliği. Yüksek Lisans Tezi. Sakarya Üniversitesi Sosyal Bilimler Enstitüsü, Turizm İşletmeciliği Anabilim Dalı, Sakarya.

Erdem, B. ve Etiz, N. (2012). Turist Rehberliği Bölümü Öğrencilerinin Rehberlik Tatbikat Gezisi Algıları: Balıkesir Üniversitesi BTİOYO Örneği. Turizm Eğitimi Konferansı Tebliğler, 17-19 Ekim 2012, Ankara, ss.323-335.

Esen, F. ve Gülmez, M. (2018a). Turist rehberliği yurtiçi uygulama gezilerinde eğitim, tur kalitesi ve tur memnuniyeti: Öğrenciler üzerine görgül bir araştırma. Necdet Hacıoğlu vd., (Ed.), içinde Turizm/ Turist Rehberliği Eğitimi (s. 155- 167). Ankara: Detay.

Esen, F. ve Gülmez, M. (2018b). Turist rehberliği yurtiçi uygulama gezilerinin öğrenciler açısından önemi: Akademisyenler ve turist rehberleri üzerine bir araştırma. Seyahat ve Otel İşletmeciliği Dergisi, 15(2), 320- 335.

Hacıoğlu, N. (2008). Türkiye'de Profesyonel Turist Rehberliği Eğitiminde Yeni Bir Yaklaşım. III. Balıkesir Ulusal Turizm Kongresi, 17- 19 Nisan 2008, Balıkesir Üniversitesi, Balıkesir. ss. 244- 247.

Karaman, S., Köroğlu, Ö. ve Köroğlu, A. (2012). Turizm Rehberliği Eğitimi Alan Öğrencilerin Rehberlik Eğitimine Yönelik Düşüncelerinin Belirlenmesi Üzerine Bir Araştırma. Turizm Eğitimi Konferans1, 17- 19 Ekim 2012, Ankara. ss. 351- 362.

Karataş, Z. (2015). Sosyal bilimlerde nitel araştırma yöntemleri, Manevi Temelli Sosyal Hizmet Araştırmaları Dergisi, 1(1), 62-80.

Kozak, M. (2015). Bilimsel araştırma: tasarım, yazım ve yazım teknikleri. Ankara: Detay Yayıncilik.

Kurgun, O. A. (2018). Hukuk ve turizmle ilgili temel kavramlar. Hüseyin Yıldırım (Ed.) içinde Turizm Hukuku ve Mevzuatı (s. 1- 9) Ankara: Detay. 
Kurnaz Akyurt, H. ve Kurnaz, A. (2018). Önlisans Turist Rehberliği Eğitimi Alan Öğrencilerin Geleceğe Ait Düşüncelerinin Belirlenmesi: Marmaris Turizm Meslek Yüksekokulu Örneği. Uluslararası Toplum Araştırmaları Dergisi, 8(8), 237- 247.

Kuşluvan, S., Çeşmeci, N. (2002). Türkiye'de Turist Rehberliği Eğitiminin Sorunları ve Yeniden Yapılandırılması. Turizm Eğitimi Konferansı, 17- 19 Ekim 2012, Ankara. ss. 235-242.

Resmî Gazete. (2012). Turist Rehberliği Meslek Kanunu. 22 Haziran 2012 tarih 28331 sayılı resmî gazete. $11 \quad$ Şubat $2020 \quad$ tarihinde [http://www.resmigazete.gov.tr/eskiler/2012/06/20120622-2.htm] internet adresinden edinilmiştir.

Şahin, B., Şahin, S. (2007). Türkiye'de Profesyonel Turist Rehberliği Eğitimi: Yaygın ve Örgün Eğitim Alanların Görüşlerinin Karşılaştırılmasına Yönelik Bir Uygulama. Çeşme Ulusal Turizm Sempozyumu, 21- 23 Kasım 2007, Çeşme, İzmir. ss. 202- 215.

Temizkan, R. ve Cankül, D. (2018). Turist rehberi adaylarının turist rehberliği eğitimi ve mesleğe kabul şartlarına karşı tutumu. Necdet Hacıoğlu vd. (Ed.) içinde Turizm/ Turist Rehberliği Eğitimi. (s. 190- 199). Ankara: Detay.

Tür, Ş. (2012). Üniversitelerde Profesyonel Turist Rehberliği Eğitimi ve Karşılaşılan Sorunlara İlişkin Çözüm Önerileri. Turizm Eğitimi Konferansı, 17- 19 Ekim 2012, Ankara. ss. 378381.

Yıldız, S. ve Demirel, B. U. (2008). Türkiye' de Profesyonel Turist Rehberliği Eğitimi Bağlamında Kültür ve Turizm Bakanlığı Kurs Programının İncelenmesi. III. Balıkesir Ulusal Turizm Kongresi, 17- 19 Nisan 2008, Balıkesir Üniversitesi, Balıkesir. ss. 255260.

Yılmaz, G. A. (2011). Lisans düzeyinde turist rehberliği eğitimi alan öğrencilerin mesleğe bakış açılarının belirlenmesine yönelik bir araştırma. Balıkesir Üniversitesi Sosyal Bilimler Enstitüsü Dergisi, 14(26), 281- 298.

Yüksel, A., Yüksel, F. (2004). Turizmde bilimsel araştırma yöntemleri, Ankara: Turhan Kitabevi. 